\title{
$17 \beta$-Estradiol induces cyto-genotoxicity on blood cells of common carp (Cyprinus carpio)
}

\author{
Luis Orozco-Hernández a , Adriana Andrea Gutiérrez-Gómez a , Nely SanJuan-Reyes a, \\ Hariz Islas-Flores a, Sandra García-Medina ${ }^{\text {b }}$, Marcela Galar-Martínez ${ }^{\text {b }}$, \\ Octavio Dublán-García a , Reyna Natividad ${ }^{\mathrm{c}}$, Leobardo Manuel Gómez-Oliván a, * \\ a Laboratorio de Toxicología Ambiental, Facultad de Química, Universidad Autónoma del Estado de México, Paseo Colón Intersección Paseo Tollocan s/n. Col. \\ Residencial Colón, 50120, Toluca, Estado de México, Mexico \\ b Laboratorio de Toxicología Acuática, Departamento de Farmacia, Escuela Nacional de Ciencias Biológicas, Instituto Politécnico Nacional, Unidad \\ Profesional Adolfo López Mateos, Av. Wilfrido Massieu S/n y Cerrada de Manuel Stampa, Col. Industrial Vallejo, C.P. 007700, Ciudad de México, Mexico \\ ${ }^{\mathrm{c}}$ Chemical Engineering Lab., Centro Conjunto de Investigación en Química Sustentable UAEM-UNAM, Carretera Toluca-Atlacomulco Km 14.5, Unidad San \\ Cayetano, Toluca, Estado de México, 50200, Mexico
}

\section{H I G H L I G H T S}

- This study aimed to evaluate $17 \beta$ estradiol-induced cyto-genotoxicity in Cyprinus carpio.

- Increases in frequency of micronuclei, caspase-3 activity and TUNELpositive cells were observed.

- The comet assay detected significant increases at 24 and $96 \mathrm{~h}$ with the $1 \mu \mathrm{g}$ and $1 \mathrm{ng} \mathrm{L}^{-1}$ of E2.

- 17 $\beta$-Estradiol induces cytogenotoxicity on C. carpio.

\section{A R T I C L E I N F O}

\section{Article history:}

Received 30 July 2017

Received in revised form

18 September 2017

Accepted 5 October 2017

Available online 6 October 2017

Handling Editor: Jim Lazorchak

\section{Keywords:}

$17 \beta$-Estradiol

Cyprinus carpio

Comet assay

Micronucleus test

TUNEL

Caspase-3
G R A P H I C A L A B S T R A C T

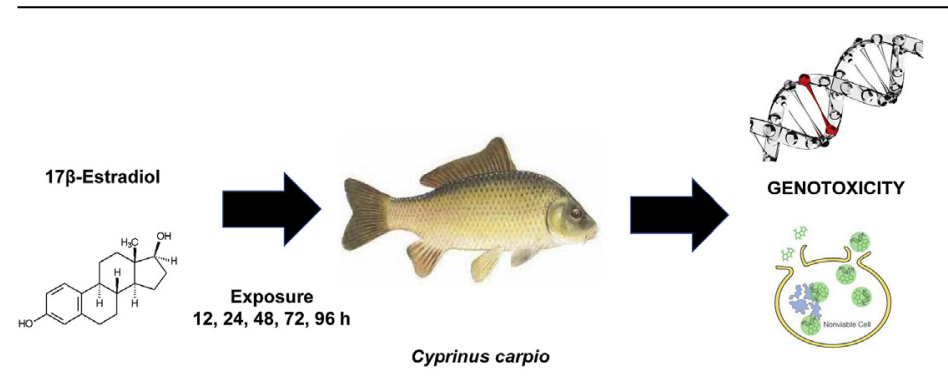

CYTOTOXICITY

\begin{abstract}
A B S T R A C T
$17 \beta$-Estradiol, a natural hormone present at high concentrations in aquatic ecosystems, affects and modifies endocrine function in animals. In recent years research workers have expressed concern over its potential effects on aquatic organisms; however, little is known about its capacity to induce genetic damage or the pro-apoptotic effects of such damage on fish. Therefore, this study aimed to evaluate $17 \beta-$ estradiol-induced cyto-genotoxicity in blood cells of the common carp Cyprinus carpio exposed to different concentrations ( $1 \mathrm{ng}, 1 \mu \mathrm{g}$ and $1 \mathrm{mg} \mathrm{L}^{-1}$ ). Peripheral blood samples were collected and evaluated by comet assay, micronucleus test, determination of caspase- 3 activity and TUNEL assay at 12,24 , 48, 72 and $96 \mathrm{~h}$ of exposure. Increases in frequency of micronuclei, TUNEL-positive cells and caspase-3 activity were observed, particularly at the highest concentration. In contrast, the comet assay detected significant increases at 24 and $96 \mathrm{~h}$ with the $1 \mu \mathrm{g}$ and $1 \mathrm{ng} \mathrm{L}^{-1}$ concentrations respectively. The set of assays used in the present study constitutes a reliable early warning biomarker for evaluating the toxicity induced by this type of emerging contaminants on aquatic species.
\end{abstract}

() 2017 Elsevier Ltd. All rights reserved.

\footnotetext{
* Corresponding author. Laboratorio de Toxicología Ambiental, Facultad de Química, Universidad Autónoma del Estado de México, Paseo Colón intersección Paseo Tollocan s/n. Col. Residencial Colón, Toluca, Estado de México, CP 50120, Mexico.

E-mail addresses: lmgomezo@uaemex.mx, lgolivan74@gmail.com (L.M. GómezOliván).
} 


\section{Introduction}

In recent years, water contamination has become a serious problem for public health and aquatic ecosystems due to domestic and industrial wastewater discharges which contain a large variety of environmental contaminants such as personal hygiene products, pharmaceuticals, and natural and synthetic hormones (Tetreault et al., 2011; Fang et al., 2012), all these are part of "emerging contaminants", a group of compounds which do not have a clear regulation to date regarding their handling and discharge into ecosystems (Kümmerer, 2001; Petrie et al., 2015; Richardson and Kimura, 2016). These substances are biologically active and although some are not considered persistent, they are introduced constantly, so they can represent a risk to ecosystem (GalarMartínez et al., 2015). In particular, concern has been expressed over the presence of steroid hormones (estrogens, progestagens and androgens), because it has been reported that members of this group can affect and modify endocrine function in animals, and are therefore known as endocrine disrupting compounds (EDCs) (Matozzo and Marin, 2008; Bolong et al., 2009; Ma et al., 2016). These chemicals can include natural estrogens (e.g., 17 $\beta$-estradiol), synthetic estrogens (e.g., $17 \alpha$-ethinylestradiol), and estrogen mimics (e.g., bisphenol A, 4-nonylphenol) (Sackett et al., 2015).

Estrogens are used in hormone replacement therapy, most often to overcome the basic symptoms associated with menopause; however, their use has made evident diverse complications, including a higher risk of developing breast, endometrial and ovarian cancer (El Habachi et al., 2014). One of the most extensively studied estrogens in mammals, and probably the most common one, is $17 \beta$-estradiol, often abbreviated E2. It has two hydroxyl groups in its molecular structure and is a natural element formed in the body. Of the three forms of estrogen produced naturally by all vertebrates, E2 is the most potent one. It is the main estrogen secreted by the ovaries and is oxidized to estriol before being eliminated. E2 also undergoes reactions such as hydroxylation, reduction, oxidation by methylation, and conjugation by liver cytochrome P450 enzymes for subsequent elimination in urine. There are no reports of E2 conjugates released into the environment having direct biological activity, but they may be a storehouse of hormone precursors since they are transformed to E2 by bacterial action (Baronti et al., 2000; Yan et al., 2013a; Heffron et al., 2016).

EDCs enter the environment, through a variety of pathways such as municipal sewage, industrial wastewaters, landfill, agricultural run-off, wash-off from roadways and underground contamination. Detection of these compounds in water is at trace levels ( $\mu \mathrm{g} \mathrm{L}^{-1}$ or even $n g \mathrm{~L}^{-1}$ ) (Bolong et al., 2009), because standard methods of sewage treatment are not completely effective in removing such substances (Zhang et al., 2007). E2 is among the most potent EDC having the potential to exert effects at extremely low concentrations (Bowman et al., 2002). In Mexico, there is only one study that reports the presence of E2 at concentrations from $0.11 \mathrm{ng} \mathrm{L}^{-1}$ to $1.72 \mathrm{ng} \mathrm{L}^{-1}$ in Xochimilco wetland (Díaz-Torres et al., 2013). Studies of aquatic wildlife that are directly exposed to contaminants, often provide early indications of potential environmental problems. A few studies report E2 can produce different harmful effects, for example, is an endocrine disrupter at concentrations above $200 \mathrm{ng} \mathrm{L}^{-1}$ in O. mykiss (Marlatt et al., 2006), affect the reproduction of 0 . javanicus at concentrations greater than $16 \mathrm{ng} \mathrm{L}^{-1}$ (Imai et al., 2005), can decrease the capacity of cellular antioxidant systems in P. aibuhitensis at concentrations greater than $0.1 \mu \mathrm{g} \mathrm{L}^{-1}$ (Lv et al., 2016) and can induce immunomodulatory changes and neurotoxicity in different organisms (Thilagam et al., 2014). On the other hand, in vitro assays have shown that at low concentrations (1-10 ng L $\left.\mathrm{L}^{-1}\right)$ of E2 induce feminization in some species of male wild fishes (Routledge et al., 1998), and changes the hepatic gene expression of the vitellogenins and choriogenins in $P$. flesus (Williams et al., 2007). Other possible endocrine-disruption effects have been observed in fish, such as reduced ovary size, lower egg viability, and delayed sexual maturity (Munkttrick et al., 1992; Hontela et al., 1995). However, there are no reports of the cytotoxic effect of exposure to E2 on aquatic organisms, which is one of the objectives of this study.

Genotoxicity is toxicity against cell's genetic material affecting its integrity (DNA damage) and may lead to mutagenicity and carcinogenicity in some circumstances (Nesslany and Benameur, 2014). The genotoxic effects of physical and chemical agents/pollutants can be monitored using a broad range of both in vivo and in vitro biomarker assays (Kumar et al., 2017). A biomarker is a cellular, molecular, genetic or physiologic response altered in an organism or population in response to a chemical stressor (Costa et al., 2010). In a previous study it was reported that E2-induced oxidative damage (Gutiérrez-Gómez et al., 2016) which could be associated with genotoxicity (Maria et al., 2008). From an ecological viewpoint, genetic damage may lead to hereditary mutations compromising the physical condition integrity of fish populations and their capacity to confront stress (Brown et al., 2009). Also, damage to the DNA of aquatic animals has been associated with reduced growth, abnormal developed and reduced survival of embryos, larvae and adults (Lee and Steinert, 2003; Reinardy et al., 2013). Analysis of DNA changes in aquatic organisms has proved an effective method for evaluating water body contamination, even when compounds are present at very low concentrations, as in the case of E2 (Frenzilli et al., 2009). Among the genotoxicity tests, comet assay and micronucleus ( $\mathrm{MNi}$ ) test are recognized due to their robustness and sensitivity to evaluate DNA damage. The MNi test measures a small subset of unrepaired DNA strand breaks, whereas the comet assay measures strand breaks and labile sites that may be removed subsequently by the DNA repair system, both studies complement each other and their methodology is easy and does not require sophisticated equipment (Końca et al., 2003; Heuser et al., 2008). On the other hand, certain genotoxic agents also induce cytotoxicity (Selvi et al., 2013), defined as the pre-lethal changes and events which occur in cells prior to necrosis (Vasquez, 2012). Lesions to DNA and inefficient repair mechanisms are crucial in the un-leashing of apoptosis (Roos and Kaina, 2006), which is a fundamental biochemical pathway of cellular death characterized by diverse morphologic changes and has a major role in the maintenance of tissue homeostasis (Simoes et al., 2013). There are two main pathways of apoptosis: extrinsic and intrinsic. The extrinsic pathway is produced in response to activation of death receptors on the cell surface, while the intrinsic pathway arises in response to extracellular signaling and internal lesions such as DNA damage (Fadeel and Orrenius, 2005). From a mechanistic perspective, apoptosis may be expected to contribute to the elimination of cells with some kind of damage, particularly that of premutagenic/mutagenic lesions (Decordier et al., 2002). An assay that relies on detection of DNA strand breaks in situ by labeling them with fluorochromes has been developed to identify and quantify apoptotic cells by fluorescence microscopy. The assay is commonly called TUNEL, the acronym of Terminal deoxynucleotidyl transferase-mediated d-UTP Nick End Labeling (Darzynkiewicz et al., 2008). TUNEL assay is certainly one of the more simple, reliable, objective, and cost-effective methods available for assessing DNA damage (Sharma et al., 2013).

The common carp Cyprinus carpio, a freshwater fish, has been introduced in Mexico in 80\% of freshwater bodies and has become an economically and ecologically important specie (Galar-Martínez et al., 2015), and has been extensively used to evaluate the cytotoxicity and genotoxicity of substances in the aquatic environment (García-Nieto et al., 2014) and is therefore a good bioindicator for 
evaluating E2-induced cyto-genotoxicity.

The present study aimed to evaluate whether E2 induces genotoxic effects by means of comet assay and micronucleus test and cytotoxic effects through caspase- 3 activity and TUNEL assay as biomarkers of damage in blood cells of the common carp C. carpio at $12,24,48,72$ and $96 \mathrm{~h}$. The nuclear anomaly or micronucleus test and comet assay, are methods wich allows the investigation of DNA damage, and have been widely applied to the investigation of environmental genotoxin effects in several fish species (Nacci et al., 1996; Mitchelmore and Chipman, 1998), while cytotoxicity is an adverse effect or interference with structures or processes essentials for cell survival, like caspase-3, an effector caspase in which both apoptosis pathways (intrinsic and extrinsic) converge. The detection of activated caspase- 3 is a valuable and specific tool for identifying apoptotic cells, even before all the morphological features of apoptosis occur (Duan et al., 2003) and confirmed by the TUNEL assay.

For the detection of double-stranded DNA breaks, TUNEL assay has been used extensively as an indicator of apoptosis and/or caspase-mediated cell death (Zhu et al., 2000). Because of this, we aimed to select this parameters as biomarkers of early warning for evaluating the toxicity induced by this type of emerging contaminants on aquatic species.

\section{Materials and methods}

\subsection{Reagents and assay materials}

The following reagents were purchased from Sigma-Aldrich (St Louis, MO): 17 $\beta$-estradiol, phosphate buffered saline (PBS, $\mathrm{pH} 7.4$ ), dimethyl sulfoxide (DMSO), ethylenediaminetetraacetic acid (EDTA), ethidium bromide (EB), 4-(2-hydroxyethyl)-1piperazineethanesulfonic acid (HEPES), 3-[(3-cholamido-propyl)dimethylammonio]-1-propane-sulfonate (CHAPS), low melting point (LMPA) and normal melting point agarose (NMPA), propidium iodide (PI), Triton X-100, dithiothreitol (DTT), DNAse I, poly-Llysine, $\mathrm{NaHCO}_{3}, \mathrm{MgSO}_{4}, \mathrm{KCl}, \mathrm{CaSO}_{4} \cdot 2 \mathrm{H}_{2} \mathrm{O}, \mathrm{NaCl}$, Trizma base and $\mathrm{NaOH}$. The CaspACE ${ }^{\mathrm{TM}}$ Assay System, Colorimetric, was purchased from Promega (Madison, WI); proteinase K from Fluka (St Louis, MO); the ApopTag ${ }^{\circledR}$ Fluorescein In Situ Apoptosis Detection S7100 kit from Chemicon International (Billerica, MA); and the LiquiPREPTM Cytology System kit from PBM (Mexico City, Mexico).

\subsection{Specimen procurement and acclimation}

Common carp (Cyprinus carpio) weighing $55.24 \pm 4.1 \mathrm{~g}$ and measuring $19.22 \pm 0.87 \mathrm{~cm}$ in length were obtained from the Tiacaque aquaculture center (State of Mexico), transported to the laboratory and acclimated for 30 days with synthetic culture medium ( $\mathrm{pH}$ 7.4), at room temperature, with constant aeration, and three fourths of the tank water was replaced every $24 \mathrm{~h}$ to maintain a healthy environment. A natural light/dark photoperiod was maintained and the organisms were fed Purina ${ }^{\mathrm{TM}}$ fish food.

\subsection{Sublethal toxicity assays}

Test systems consisting in glass tanks $(120 \times 80 \times 40 \mathrm{~cm})$ filled of reconstituted water with $\mathrm{NaHCO}_{3}\left(174 \mathrm{mg} \mathrm{L} \mathrm{L}^{-1}\right), \mathrm{MgSO}_{4}$ (120 mg L $\left.{ }^{-1}\right), \mathrm{KCl}\left(8 \mathrm{mg} \mathrm{L}^{-1}\right)$ and $\mathrm{CaSO}_{4} \cdot 2 \mathrm{H}_{2} \mathrm{O}\left(120 \mathrm{mg} \mathrm{L}^{-1}\right)$ were maintained at room temperature with constant aeration and a natural light/dark photoperiod (Commission Directive 92/69/EEC). Static systems with six carp each were used and no food was provided to specimens during exposure. Three environmentally relevant concentrations of E2 were tested: $1 \mathrm{ng}, 1 \mu \mathrm{g}$, and $1 \mathrm{mg} \mathrm{L}^{-1}$. The exposure times used were 12, 24, 48, 72 and $96 \mathrm{~h}$. An E2-free control system with six carp was set up for each exposure time, and a positive control group was set up for each test and exposure time; the assays were performed in triplicate using a total of 900 fish. After the exposure time is over, fish were removed from the systems and placed in a tank containing a xylocaine solution $\left(0.02 \mathrm{mg} \mathrm{mL}^{-1}\right)$ to anesthetize specimens. Blood was collected from the caudal vein with a heparinized hypodermic syringe.

Blood samples $(100 \mu \mathrm{L})$ were diluted with $600 \mu \mathrm{L}$ PBS. These samples were used to perform the comet assay and one part of cell suspension was used to make smears to evaluate the presence of micronucleus. For the TUNEL assay, $100 \mu \mathrm{L}$ of cell suspension was mixed with $1 \mathrm{~mL}$ of preservation solution from the liquid-based cytology kit which had been kept refrigerated prior to mounting of the samples. For determination of caspase- 3 activity, $100 \mu \mathrm{L}$ of cell suspension was frozen at $-20{ }^{\circ} \mathrm{C}$, centrifuged at $16000 \times \mathrm{g}$ and $-4{ }^{\circ} \mathrm{C}$ for $15 \mathrm{~min}$, and the supernatant used to evaluate activity.

\subsection{Comet assay}

The protocol described by Martínez-Tabche et al. (2004) and Cariño-Cortés et al. (2010) for rainbow trout and mouse cells was modified as follows: frosted slides were covered with a layer of $1 \%$ NMPA $(100 \mu \mathrm{L})$ and dried at room temperature, later a second layer of $10 \mu \mathrm{L}$ of cell suspension plus $0.75 \%$ LMPA ( $75 \mu \mathrm{L}$ ) was placed on the same slide, spread, and solidified on ice. Slides were refrigerated at $4{ }^{\circ} \mathrm{C}$ for $30 \mathrm{~min}$ and placed in lysis solution $(2.5 \mathrm{M} \mathrm{NaCl}$, $100 \mathrm{mM}$ EDTA, $10 \mathrm{mM}$ Trizma base, 10\% DMSO and 1\% Triton X-100, $\mathrm{pH} 10$ ) for $1 \mathrm{~h}$. Once the time has elapsed, slides were placed in the electrophoresis chamber which contained an alkaline solution (300 mM NaOH and $1 \mathrm{mM}$ EDTA, pH > 13). Electrophoresis was performed at $300 \mathrm{~mA}$ and $25 \mathrm{~V}$ for $20 \mathrm{~min}$. The process was halted by rinsing in Trizma base $(0.4 \mathrm{M}, \mathrm{pH} 7.4)$ and slides were to dry at room temperature. Intraperitoneal (i.p.) injection with $20 \mathrm{mg}$ cyclophosphamide per $\mathrm{kg}$ of fish weight was used in the positive control. Nucleoids from each slide were stained with $50 \mu \mathrm{L}$ EB. Scoring was done with an epifluorescence microscope (Zeiss Axiophot-1) fitted with digital camera (ZWS-47DE) and imaging software (Zeiss KS400 v3.01). We measured the total length containing the nucleus and the migrated DNA $(\mathrm{T})$, and divided the result by the nucleus diameter $(\mathrm{N})$ so as to obtain the $\mathrm{T} / \mathrm{N}$ ratio in 100 nucleoids per fish, concentration and exposure time (CariñoCortés et al., 2010).

\subsection{Micronucleus test}

The cell suspension obtained from each specimen was fixed with pure ethanol on a slide for $3 \mathrm{~min}$, then stained with a $10 \%$ solution of Giemsa in PBS (pH 6.7) for $10 \mathrm{~min}$, and rinsed in tap water. 1000 erythrocytes per fish were analyzed in a light microscope. MNi frequency was expressed as the percentage of micronucleated cells per 1000 cells (Cavas and Ergene-Gözükara, 2005). Intraperitoneal (i.p.) injection with $20 \mathrm{mg}$ cyclophosphamide per $\mathrm{kg}$ of fish weight was used as a positive control.

\subsection{Determination of Caspase-3 activity}

The substrate [N-acetyl-Asp-Glu-Val-Asp p-nitroanilide (AcDEVD-pNA)] in the CaspACE ${ }^{\mathrm{TM}}$ colorimetric assay kit used to determine Caspase- 3 activity, binds to the enzyme, releasing the chromophore pNA. A blank was prepared using $54 \mu \mathrm{L}$ deionized water and the reaction mixture, which includes: $32 \mu \mathrm{L}$ caspase buffer (312.5 Mm HEPES pH 7.5, 31.25\% saccharose, 0.3125\% CHAPS (3-[(3-cholamidopropyl)- dimethylammonio]-1-propane-sulfonate)), $2 \mu \mathrm{L}$ DMSO and $10 \mu \mathrm{L}$ dithiothreitol (DTT, $100 \mathrm{mM}$ ). For the control group and groups exposed to E2 (1 ng L $\mathrm{L}^{-1}, 1 \mu \mathrm{g} \mathrm{L}^{-1}$ and 
$1 \mathrm{mg} \mathrm{L}^{-1}$ ), the following were used: $20 \mu \mathrm{L}$ blood, reaction mixture and $54 \mu \mathrm{L}$ deionized water; for the positive control was used: reaction mixture, $20 \mu \mathrm{L}$ cellular extract [Jurkat cells (ATCC\#TIB-152) treated with anti-Fas $\mathrm{mAb}\left(50 \mathrm{ng} \mathrm{mL}^{-1}\right.$, MBL International) in fetal bovine serum (FBS)] and $34 \mu \mathrm{L}$ deionized water. Finally, for inhibited apoptosis samples: reaction mixture, $20 \mu \mathrm{L}$ cellular extract [Jurkat cells (ATCC\#TIB-152) treated with anti-Fas mAb (50 ng $\mathrm{mL}^{-1}$, MBL International) in FBS and $125 \mu \mathrm{L}$ of the inhibitor Z-VAD-FMK (carbobenzoxy-valyl-alanyl-aspartyl-(O-methyl)-fluoromethylketone, $20 \mathrm{mM}$ )] and $34 \mu \mathrm{L}$ deionized water.

After all solutions had been transferred, $2 \mu \mathrm{L}$ of substrate DEVDpNA was added to each well. Absorbance was read at $405 \mathrm{~nm}$ and the specific activity of caspase- 3 was calculated. Results were expressed as nM free pNA $\mathrm{h}^{-1} \mu \mathrm{g}$ protein $^{-1}$. Protein content as determined by the Bradford (1976) method was used to normalize the results of enzymatic activity.

\subsection{TUNEL assay}

For this test, the ApopTag Fluorescein S7110 kit was used. Samples $(100 \mu \mathrm{L})$ of the cell suspension diluted $1: 15$ in preservative solution were centrifuged at $800 \times \mathrm{g}$ for $5 \mathrm{~min}$ at $4{ }^{\circ} \mathrm{C}$, and the cell pellet was resuspended in $50 \mu \mathrm{L}$ mounting solution from the cytology system kit. Later, $1 \mu \mathrm{L}$ of this suspension was placed on a microscope slide with poly-L-lysine, dried for $5 \mathrm{~min}$ at $60^{\circ} \mathrm{C}$. After drying, fixed with cold acetone for $10 \mathrm{~min}$, and hydrated in successive changes (from 100\% to 50\%) of xylene, ethanol and water. The cells were next treated with proteinase $\mathrm{K}\left(20 \mu \mathrm{g} \mathrm{mL}^{-1}\right)$ for $10 \mathrm{~min}$, then washed with PBS. After, $60 \mu \mathrm{L}$ equilibrium buffer was added, and incubation with $65 \mu \mathrm{L} \mathrm{TdT}$ enzyme at $37{ }^{\circ} \mathrm{C}$ for $60 \mathrm{~min}$. Finally, the cells were rinsed in PBS prior to adding anti-FITC conjugate that was use as a cell marker, and were maintained at room temperature for $30 \mathrm{~min}$, then were again rinsed in PBS, stained with PI $\left(1.5 \mu \mathrm{g} \mathrm{mL}^{-1}\right)$, and observed under an epifluorescence microscope equipped with a digital camera. In our assay, a negative control sample was included, consisting of cells treated as described above but without addition of TdT, while the positive control sample consisted of cells loaded with DNase I $\left(1 \mu \mathrm{g} \mathrm{mL}^{-1}\right)$. Rate of apoptosis was expressed as the percentage of TUNELpositive cells in 100 cells per sample.

\subsection{Pearson's correlation between geno and cytotoxicity biomarkers}

Pearson's correlation analysis was used to find potential correlations between geno (comet assay and micronucleus test)- and cytotoxicity (TUNEL assay and Caspase-3 activity) biomarkers. The Sigmastat v2.03 program was used.

\subsection{Statistical analysis}

All variables were expressed as the mean \pm SEM. To compare the means for each variable, a one-way repeated measures ANOVA was performed, followed by Dunn's test. Results of Cas-3 activity were subjected to a Friedman repeated measures ANOVA by ranks, followed by Student-Newman-Keuls post hoc multiple comparison tests. The significance level was set at $p<0.05$, and SigmaPlot v12.3 software was used.

\section{Results}

A tendency towards increased DNA damage compared to the control group was seen at most exposure times with the $1 \mathrm{ng} \mathrm{L^{-1 }}$ concentration of E2, but was significant only at $96 \mathrm{~h}(p>0.05)$. A similar behavior was found with $1 \mu \mathrm{g} \mathrm{L}^{-1}$, the highest significant increase occurring at $24 \mathrm{~h}$. Damage index values with the $1 \mathrm{mg} \mathrm{L}^{-1}$ concentration did not differ from control group values at any exposure time, but a peak was observed at $12 \mathrm{~h}$. The positive control was increased significantly in approximately $27-30 \%$ respects to control group in all exposure times (Fig. 1).

Low percentages of $\mathrm{MNi}$ were found in control group cells at all exposure times $(0.100 \pm 0.014)$, while test concentrations showed significant increases at all exposure times, and a concentrationdependent peak at $48 \mathrm{~h}$. The positive control showed significant difference in approximately $100-110 \%$ respects to control group in all exposure times (Fig. 2).

Increases in activity of Cas-3 with respect to the control group were found with all concentrations at all exposure times, except with the $1 \mu \mathrm{g} \mathrm{L}^{-1}$ concentration where a $1 \%$ reduction relative to the control group was found at $96 \mathrm{~h}$. Activity levels were observed to be similar at all exposure times, except at $48 \mathrm{~h}$ when the group exposed to $1 \mathrm{mg} \mathrm{L}^{-1}$ had a significant, more than four-fold higher

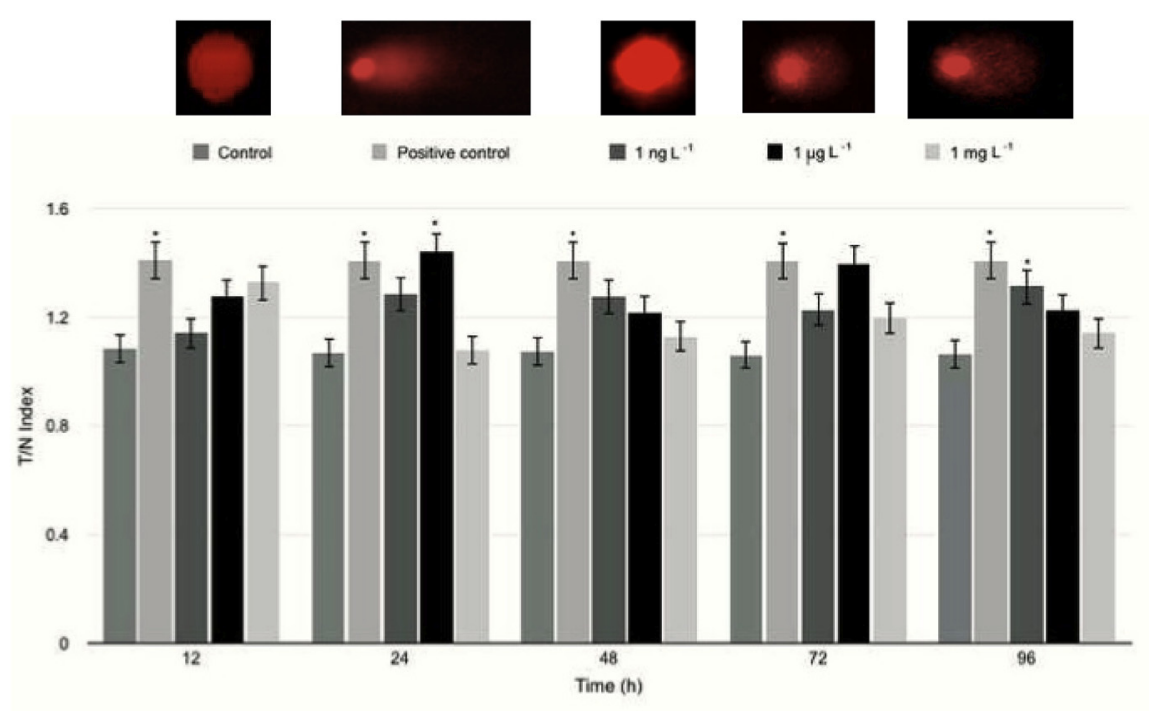

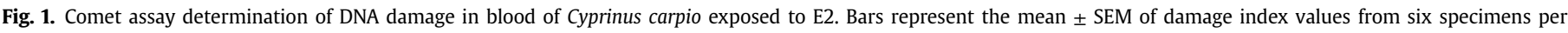
concentration and exposure time (100 nucleoids per fish). The assay was performed in triplicate. *Significantly different from the control group ( $\mathrm{p} \leq 0.05)$. 

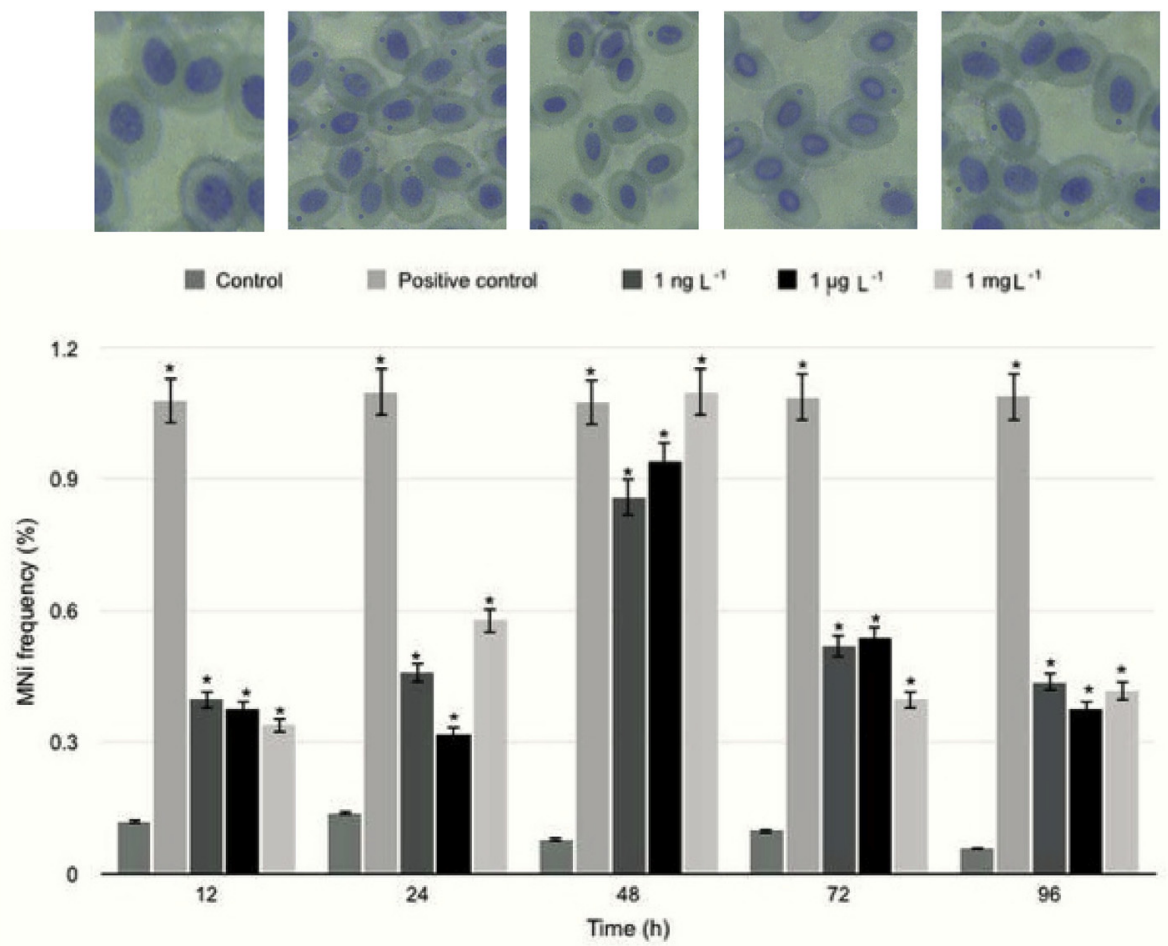

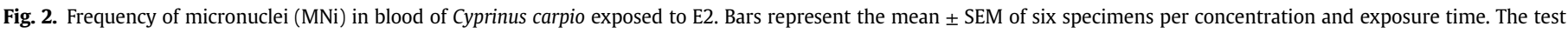
was performed in triplicate. *Significantly different from the control group $(\mathrm{p} \leq 0.05)$.

increase with respect to the control group and all other concentrations and exposure times. The positive control was increased significantly in approximately $100 \%$ respects to control group in all exposure times (Fig. 3).

The percentage of TUNEL-positive cells in the control group was within $27-35 \%$ at all exposure times. Groups exposed to the $1 \mathrm{ng}$ and $1 \mu \mathrm{g} \mathrm{L}^{-1}$ concentrations showed a significant increase from $48 \mathrm{~h}$ on and up to $72 \mathrm{~h}$ that was approximately $9 \%$ and $12 \%$ respectively above mean values in the control group. A similar behavior was observed in the group exposed to $1 \mathrm{mg} \mathrm{L}^{-1}$, but beginning at $12 \mathrm{~h}$. The positive control showed significance in approximately $100-110 \%$ respects to control group in all exposure times (Fig. 4).

Table 1 shows, respectively, the correlations observed between the geno- and cytotoxicity biomarkers respectively at the different exposure times, as can be seen, there is a higher correlation in the concentration of $1 \mathrm{ng}$ at $48 \mathrm{~h}$ in the biomarkers of genotoxicity, while this correlation is observed in the concentration of $1 \mu \mathrm{g}$ in cytotoxicity case.

\section{Discussion}

The aquatic environment is the ultimate recipient of the increasing amount and range of contaminants, which could be potentially genotoxic and carcinogenic (Claxton et al. 1998). Studies regarding E2 effects on fish have been focused on endocrine aspects. It is known that it may alter gonadosomatic index in males, reduce egg production in females, induce vitellogenesis in males and juveniles as well as decrease fertility (Mills et al., 2001; Kang et al., 2002). However, it has also been reported that E2 can stimulate the production of reactive oxygen species (ROS), which results in oxidative damage to aquatic organisms (Gutiérrez-Gómez et al., 2016). Biomarkers for monitoring environmental health are informative tools for detecting exposure and effects of chemical pollutants, including EDCs (Adeogun et al., 2016). Among the techniques to detect genotoxic effects, the comet assay detects DNA single-strand breaks (strand breaks and incomplete excision repair sites), alkali-labile sites and cross-linking, with the single-cell approach typical of cytogenetic assays (Kumaravel and Jha, 2006; Kumaravel et al., 2007). The positive control that was used was cyclophosphamide, an alkylating agent, it has been shown to possess various genotoxic and carcinogenic effects (Wang et al., 2006). In our study, comet assay found a significant increase in $1 \mathrm{ng}$ and $1 \mu \mathrm{g} \mathrm{L}^{-1}$ of E2 (Fig. 1). This increase was time-dependent, occurring at $24 \mathrm{~h}$ with the higher concentration and $96 \mathrm{~h}$ with the lower one. In fish exposed to $1 \mathrm{mg} \mathrm{L}^{-1}$, a non-significant maximum increase of approximately $24 \%$ above control group values was seen at $12 \mathrm{~h}$. The damage found in blood cells of $C$. carpio may be explained by the E2 biotransformation in which are formed 2- and 4-hydroxyestradiol (2-OH-E2 and 4-OH-E2) (Mauras et al., 2015). In fishes, E2 metabolism occurs predominantly in the liver (Butala et al., 2004). Free-radical intermediates and ROS formed during biotransformation of xenobiotics can initiate macromolecular changes, namely DNA damage, necrosis and apoptosis (Van der Oost et al., 2003). In humans, also the liver is the primary site of E2 metabolism, where the rate of 2-hydroxylation catalized by P450 1A2, P450 3A3 y P450 3A4, greatly exceeds that of 4hydroxylation (Hayes et al., 1996), both metabolites can directly or indirectly damage DNA, proteins, and lipids through the generation of reactive free radicals by the reductive-oxidative cycling of these catechol estrogens between their semiquinone and quinone forms (Liehr and Roy, 1990; Dwivedy et al., 1992; Nutter et al., 1994). Quinone intermediates may react with purine bases of DNA to form depurinating adducts that generate highly mutagenic apurinic sites. Several types of indirect DNA damage are caused by estrogeninduced oxidants, such as oxidized DNA bases, DNA strand breakage, and adduct formation by reactive aldehydes derived from lipid hydroperoxides (Cavlieri et al., 2000). On the other hand, 
E Control Positive control a $1 \mathrm{ng} \mathrm{L}^{-1} \quad 1 \mu \mathrm{L} \mathrm{L}^{-1}$ I $1 \mathrm{mg} \mathrm{\textrm {L } ^ { - 1 }}$

40

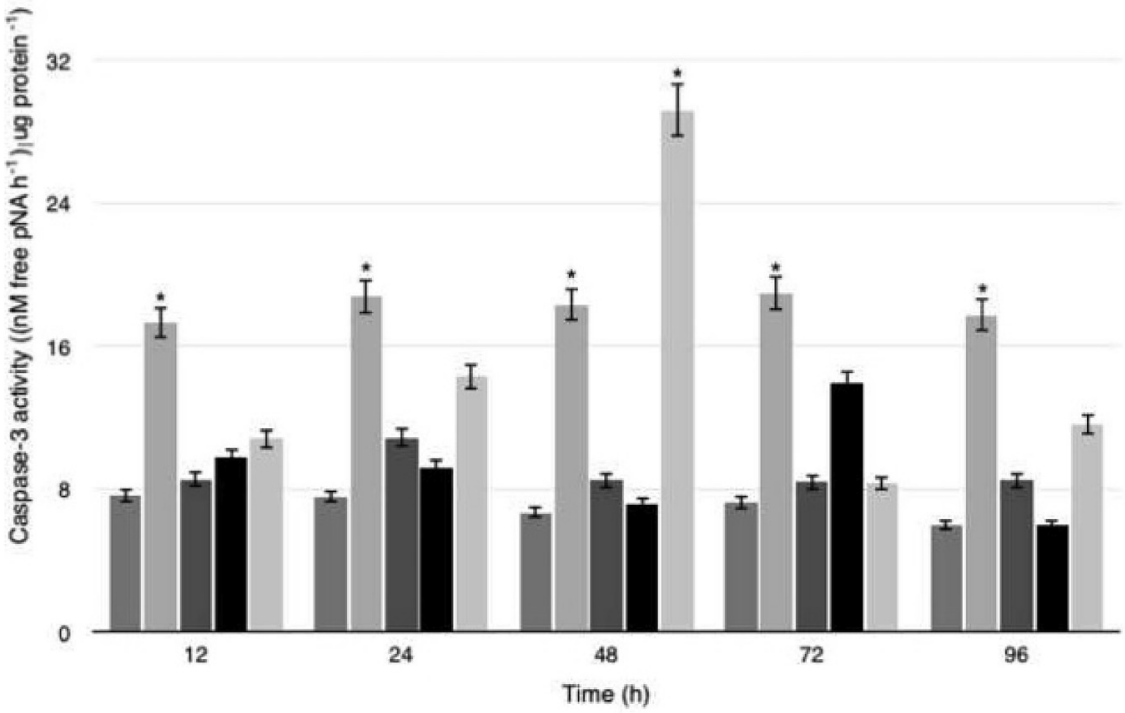

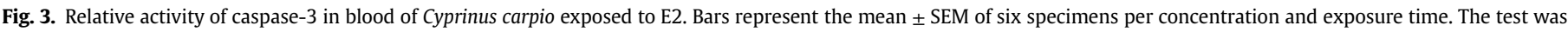
performed in triplicate. *Significantly different from the control group and all other test concentrations $(p \leq 0.05)$.
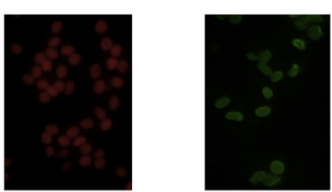

Control

III Positive control
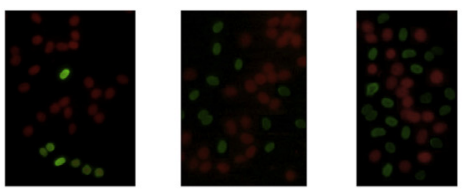

$1 \mathrm{ng} \mathrm{\textrm {L } ^ { - 1 }}$

- $1 \mu \mathrm{g} \mathrm{L}^{-1}$

IIII $1 \mathrm{mg} \mathrm{L}^{-1}$

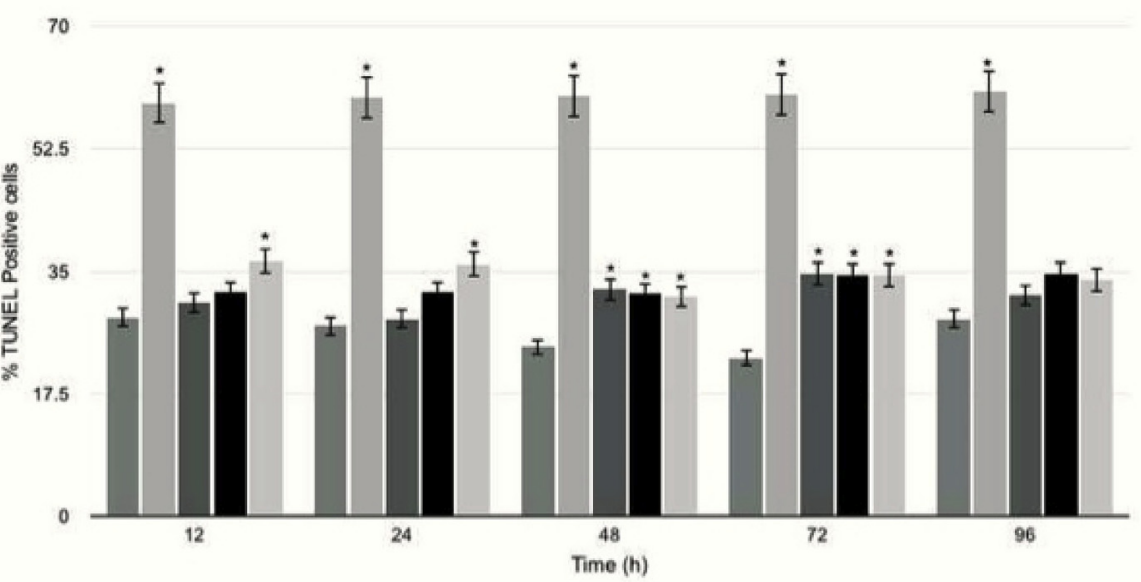

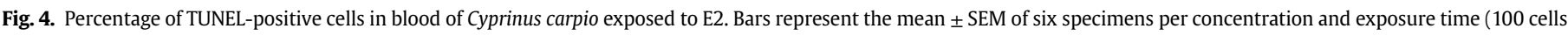
per fish). The assay was performed in triplicate. *Significantly different from the control group $(\mathrm{p} \leq 0.05)$.

enzymes, such as glutathione, a major endogenous antioxidant, which plays a crucial role in protecting cells from exogenous and endogenous toxins, and which exists in the glutathione reduced (GSH) and glutathione disulphide (GSSG), was reported by Lv et al. (2016) an increased dose dependent, specifically the activity of GSSG of $P$. aibuhitensis exposed to E2; in addition to this, GutiérrezGómez et al. (2016) also found a significant increase in the activity of the antioxidant enzymes superoxide dismutase, the first defense and the main enzyme responsible for the conversion of superoxide anion to hydrogen peroxide, and glutathione peroxidase in blood of C. carpio exposed to concentration of $1 \mathrm{mg} \mathrm{L}^{-1} \mathrm{E} 2$ at $96 \mathrm{~h}$; the increase of these enzymes could explain the results in the comet assay that demonstrated less damage to concentration of $1 \mathrm{mg} \mathrm{L}^{-1}$, evidencing a greater activity as a mechanism to counteract 
Table 1

Pearson's correlation between A. Genotoxicity and B. Cytotoxicity biomarkers in blood of C. carpio.

A.

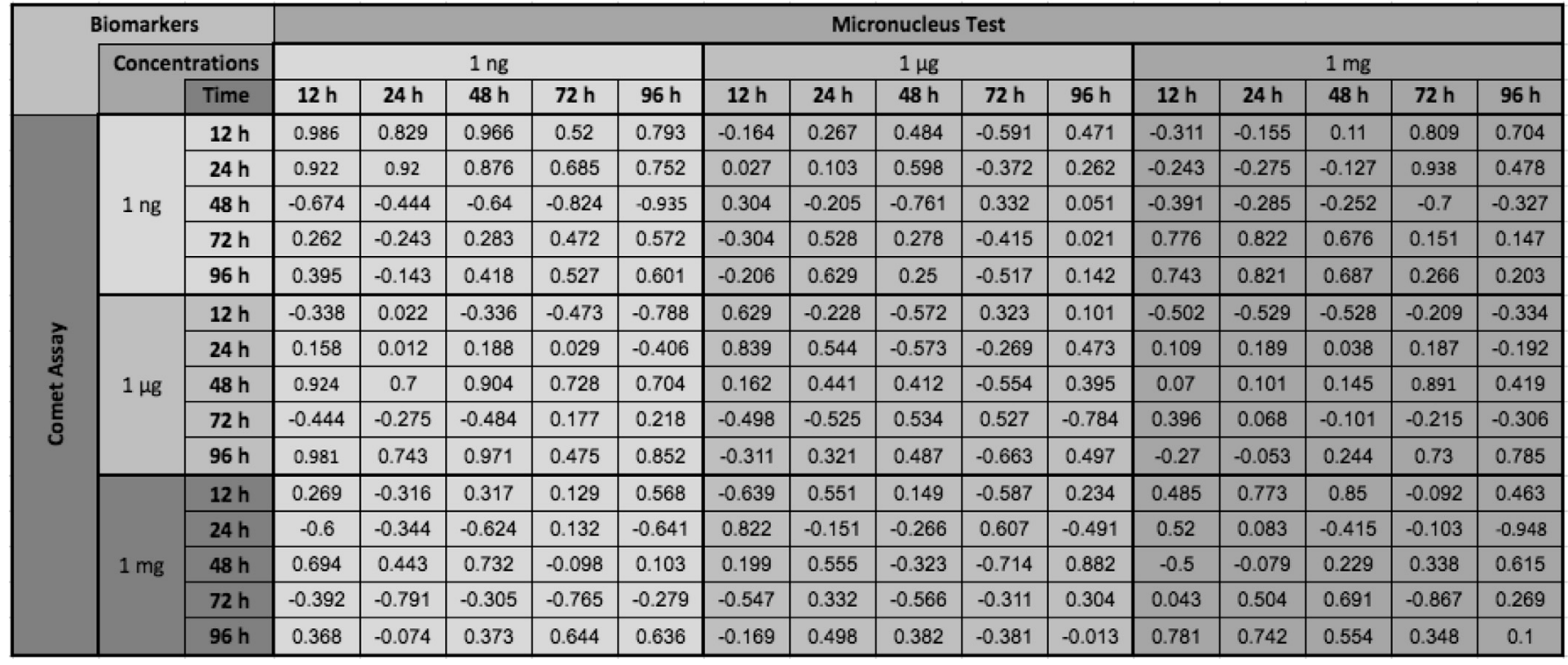

B.

\begin{tabular}{|c|c|c|c|c|c|c|c|c|c|c|c|c|c|c|c|c|c|}
\hline \multicolumn{3}{|c|}{ Biomarkers } & \multicolumn{15}{|c|}{ Caspase-3 } \\
\hline & \multicolumn{2}{|c|}{ Concentrations } & \multicolumn{5}{|c|}{$1 \mathrm{ng}$} & \multicolumn{5}{|c|}{$1 \mu \mathrm{g}$} & \multicolumn{5}{|c|}{$1 \mathrm{mg}$} \\
\hline & & Time & $12 \mathrm{~h}$ & $24 \mathrm{~h}$ & $48 \mathrm{~h}$ & $72 \mathrm{~h}$ & $96 \mathrm{~h}$ & $12 \mathrm{~h}$ & $24 \mathrm{~h}$ & $48 \mathrm{~h}$ & $72 \mathrm{~h}$ & $96 \mathrm{~h}$ & $12 \mathrm{~h}$ & $24 \mathrm{~h}$ & $48 \mathrm{~h}$ & $72 \mathrm{~h}$ & $96 \mathrm{~h}$ \\
\hline \multirow{15}{*}{ 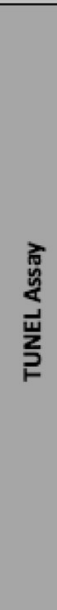 } & \multirow{5}{*}{$1 \mathrm{ng}$} & $12 \mathrm{~h}$ & -0.579 & -0.160 & -0.593 & -0.330 & -0.326 & 0.429 & 0.283 & 0.856 & 0.477 & 0.046 & -0.566 & 0.786 & -0.495 & -0.647 & 0.319 \\
\hline & & $24 \mathrm{~h}$ & 0.545 & -0.186 & 0.402 & 0.300 & -0.769 & 0.374 & 0.804 & -0.328 & 0.466 & -0.621 & -0.327 & -0.097 & 0.123 & 0.167 & 0.505 \\
\hline & & $48 \mathrm{~h}$ & 0.541 & 0.432 & -0.556 & -0.381 & -0.238 & 0.409 & 0.415 & 0.096 & 0.419 & -0.887 & -0.247 & -0.359 & 0.709 & -0.659 & 0.106 \\
\hline & & $72 \mathrm{~h}$ & 0.309 & 0.026 & -0.387 & -0.250 & -0.735 & 0.631 & 0.855 & 0.317 & 0.720 & -0.869 & -0.645 & 0.148 & 0.216 & -0.611 & 0.546 \\
\hline & & $96 \mathrm{~h}$ & 0.146 & 0.329 & -0.307 & -0.529 & 0.763 & -0.561 & -0.513 & -0.120 & -0.623 & -0.270 & 0.296 & -0.604 & 0.630 & -0.159 & -0.350 \\
\hline & \multirow{5}{*}{$1 \mu \mathrm{g}$} & $12 \mathrm{~h}$ & 0.496 & 0.080 & -0.153 & 0.054 & -0.844 & 0.729 & 0.870 & 0.061 & 0.805 & -0.763 & -0.485 & 0.034 & 0.241 & -0.391 & 0.457 \\
\hline & & $24 \mathrm{~h}$ & 0.518 & 0.022 & 0.136 & -0.211 & -0.007 & -0.227 & 0.264 & -0.360 & -0.188 & -0.742 & -0.072 & -0.535 & 0.557 & 0.057 & 0.198 \\
\hline & & $48 \mathrm{~h}$ & -0.011 & -0.469 & 0.953 & 0.727 & -0.251 & -0.166 & 0.067 & -0.523 & -0.133 & 0.500 & 0.185 & 0.120 & -0.512 & 0.908 & 0.122 \\
\hline & & $72 \mathrm{~h}$ & 0.241 & -0.018 & 0.807 & 0.565 & 0.418 & -0.532 & -0.522 & -0.826 & -0.596 & 0.517 & 0.700 & -0.513 & 0.065 & 0.922 & -0.422 \\
\hline & & $96 \mathrm{~h}$ & -0.388 & -0.496 & -0.393 & -0.862 & -0.115 & -0.256 & 0.494 & 0.652 & -0.124 & -0.749 & -0.824 & 0.399 & -0.136 & -0.508 & 0.749 \\
\hline & \multirow{5}{*}{$1 \mathrm{mg}$} & $12 \mathrm{~h}$ & -0.349 & -0.225 & 0.424 & 0.598 & -0.133 & 0.111 & -0.179 & -0.055 & 0.092 & 0.847 & 0.201 & 0.427 & -0.663 & 0.463 & -0.128 \\
\hline & & $24 \mathrm{~h}$ & -0.243 & 0.521 & -0.727 & -0.198 & 0.340 & 0.279 & -0.471 & 0.439 & 0.178 & 0.370 & 0.207 & 0.103 & 0.093 & -0.578 & -0.511 \\
\hline & & $48 \mathrm{~h}$ & $\begin{array}{r}-0.738 \\
\end{array}$ & -0.464 & 0.264 & 0.173 & 0.144 & -0.263 & -0.301 & 0.253 & -0.254 & 0.817 & 0.009 & 0.618 & -0.826 & 0.347 & 0.024 \\
\hline & & $72 \mathrm{~h}$ & -0.701 & -0.902 & 0.448 & 0.051 & -0.353 & -0.218 & 0.347 & 0.340 & -0.092 & 0.283 & -0.529 & 0.836 & -0.978 & 0.351 & 0.665 \\
\hline & & $96 \mathrm{~h}$ & -0.497 & -0.181 & 0.328 & 0.395 & 0.276 & -0.213 & -0.521 & -0.024 & -0.262 & 0.966 & 0.350 & 0.323 & -0.598 & 0.465 & -0.304 \\
\hline
\end{tabular}

oxidative DNA damage induced by E2. However, occasionally, such damage is not effectively repaired or is erroneously repaired, eliciting changes in the original DNA sequence (Cavalieri and Rogan, 2014), for this reason, and to evidence the damage, the comet assay is often applied in conjunction with the MNi test, that due to its simplicity, is one of the most applicable techniques to identify genomic alterations in environmental animals. MNi are formed in the process of cell division and their expression can occur at different times after the DNA damage event, depending on the cell cycle kinetics and the mechanism of induction (Bolognesi and Hayashi, 2011). Their presence in a cell population such as circulating erythrocytes is indicative of the end of such lesions (Canistro et al., 2012). In the present study, significant increases in MNi frequency occurred with all concentrations from $12 \mathrm{~h}$ on, reaching a peak at $48 \mathrm{~h}$ and declining thereafter (Fig. 2). In the literature, appearance of $\mathrm{MNi}$ in aquatic organisms is said to take place approximately 5 or 10 days after exposure, even though shorter periods averaging $2-3$ days have been reported in most fish species (Udroiu, 2006). E2 can also induce damage at the chromosome level. This compound is said to induce clastogenic and aneugenic effects detectable by micronucleus test. Such damage is generally considered an indicator of genomic instability (Kabil et al., 2008; Kumar et al., 2015). Among the potential targets for induction of numerical chromosomal aberrations or chromosome breakage are the mitotic spindle (microtubules and centrioles), DNA and proteins regulating it, and centromeres. Alterations in these cell components are induced by E2 metabolites directly via covalent bonding or indirectly by free radical formation, as discussed above. Similar results regarding the genotoxicity of E2 have been found in other fish species. For instance, this compound has been reported to 
induce nuclear anomalies in erythrocytes of $S$. aurata exposed to $4000 \mathrm{ng} \mathrm{L}^{-1}$ for 10 days (Teles et al., 2005). The same effect was observed in D. labrax juveniles treated with 200 and $2000 \mathrm{ng} \mathrm{L}^{-1}$ for 10 days (Teles et al., 2006). In the latter species, using identical concentrations, Maria et al. (2008) found loss of DNA integrity in liver, gill, kidney and blood. At the same concentrations, loss of DNA integrity was found in liver of Japanese sea bass after 5, 10 and 15 days of exposure (Thilagam et al., 2010). Similarly, in gonad of Carassius auratus exposed to a range of concentrations from 38 to $145 \mathrm{ng} \mathrm{L}^{-1}$ for 3, 7, 10 and 14 days, genetic damage increased as determined by comet assay (Yan et al., 2013b). In the review, most authors agree that E2-induced genotoxicity is related to oxidative stress. Pearson's correlation about the genotoxicity data showed that there is a high correlation between the comet assay and micronucleus test in the concentration of $1 \mathrm{ng}$ at $48 \mathrm{~h}$. Kim and Hyun (2006) found a concordance between the comet assay and the micronucleus test, their results shows that the sensitivity of the comet assay seemed to be higher than the micronucleus test using C. carpio.

Therefore, combining the use of the comet assay and micronucleus test in the present study enabled detection of multiple damage at different levels in a much shorter time period than the ones used by other authors. Both techniques are preferred in aquatic toxicology studies due to their high sensitivity and their are also an excellent tool for evaluating environmental contaminants with diverse molecular targets, as in the case of E2 (Kumar et al., 2015).

The organisms respond to the presence of DNA lesions by activating cell cycle checkpoint and repair mechanisms, and have the possibility of eliminating the damaged cells by triggering their death. Induction of apoptosis has been recognized as a possible outcome of DNA damage (Norbury and Zhivotovsky, 2004). Estradiol promotes cell survival or death depending on the context of the cells or tissue in question (Williams et al., 2007). In mammalian cells, these antagonistic effects are mediated by different estrogen receptors: ER $\alpha$, which promote cell cycle progression and apoptosis prevention, and ER $\beta$, which stimulate Fas ligand expression (extrinsic pathway) and promote caspase activation (Acconcia et al., 2005). On the other hand, in eukaryotic cells, when a large number of DNA lesions are present, the cell cycle is arrested at G1 to prevent DNA replication, allowing time for errors to be repaired or apoptosis to be initiated (intrinsic pathway). In rat spermatogenic cells, both the extrinsic pathway, mediated by Fas receptors, and the intrinsic pathway where the mitochondrion is involved, have been shown to be implicated in cell death following exposure to E2 (Mishra and Shaha, 2005).

Irrespective of the pathway, the signaling cascades converge on activation of Caspase-3, an inactive proenzyme located in the cytosol of non-apoptotic cells wich is activated during early apoptosis and acts as an effector protease that cleaves cellular substrates and produce morphological alterations characteristic to apoptosis (Hirata et al., 1998), this test detect membrane and protein alterations associated with apoptosis and allows the observation of early levels and effects associated with xenobiotic exposure (Sweet et al., 1999); for that reason, determination of the activity of caspase-3 has been extensively used as an indicator of apoptosis (Dahmer, 2005). The monoclonal antibodies (mAbs) that bind to the cell surface receptor Fas, are apoptosis inducer (Fisher et al., 1995). In this assay anti-Fas mAb was used as the positive control. A significant increase $(p<0.05)$ in specific activity of caspase-3 was observed in the positive control with respect to the control group at all exposure times. Activity levels with the lowest concentration were similar at most exposure times, while the $1 \mu \mathrm{g} \mathrm{L}^{-1}$ concentration produced a peak at $72 \mathrm{~h}$ that was not significant with respect to other exposure times, and a slight reduction (to 99\%) at
$96 \mathrm{~h}$. In carp exposed to $1 \mathrm{mg} \mathrm{L} \mathrm{L}^{-1}$, the highest significant activity was evidenced at $48 \mathrm{~h}$ (Fig. 3). The compound E2 modulates the regulation of apoptotic signaling pathways. In oocytes of teleost fishes, it induces cell proliferation, interrupting cell death and steroidogenesis as long as estrogen concentrations are at normal physiological levels. In contrast, at higher concentrations, E2 promotes increased apoptosis (Nadzialek and Kestemont, 2010), as seen in the present study.

During apoptosis, after caspases have been activated by the cells, chromatin condensation occurs, followed by activation or synthesis of diverse calcium-dependent nucleases that cleave both strands of the double helix at nucleosome binding sites, resulting in specific fragmentation (Vazzana et al., 2014). TUNEL is an assay based on incorporation of biotinylated nucleotides conjugated to bromodeoxyuridine (BrdU) at the $3^{\prime} \mathrm{OH}$ ends of the DNA fragments that form during apoptosis. TUNEL assay may be considered generally as a method for the detection of DNA damage (DNA fragmentation), and under the appropriate circumstances, more specifically as a method for identifying apoptotic cells (Lawry, 2004).

Therefore, this assay should be performed in combination with another method of apoptotic cell detection, such as Cas-3 activity determination. In the present study, significant increases in TUNELpositive cells in the highest concentration and both $1 \mathrm{ng}$ and $1 \mu \mathrm{g} \mathrm{L}^{-1}$ at 48 and $72 \mathrm{~h}$ (Fig. 4) were found despite the fact that the relative activity of Caspase 3 was elevated but did not differ significantly. These results suggest that a potential inhibition of apoptosis was not carried out completely. When damage is such that the cell is unable to repair itself, mechanisms directing the cell to die are activated (Zhou and Elledge, 2000). Pearson's correlation about the cytotoxicity data showed that there is a high correlation between TUNEL assay and caspase- 3 activity in the concentration of $1 \mu \mathrm{g}$ at $48 \mathrm{~h}$.

Due to all the above, the cytotoxicity and genotoxicity data found in this study, could be related to the ability of E2 to generate oxidative stress. This was proven in a previous study already published in which it was demonstrated that E2 is capable of generating oxidative stress in gill, brain, liver, kidney and blood of common carp (Cyprinus carpio) at the same concentrations used in this study (Gutiérrez-Gómez et al., 2016). The significant increase in damage index values represents accumulation of DNA damage but, as evidenced by the biomarkers of apoptosis used in the study, the cell death process may mask this effect. For instance, in fish exposed to $1 \mathrm{mg} \mathrm{L}^{-1}$ no significant increase was found by comet assay, yet this concentration had the highest increases in TUNELpositive cells and relative activity of Caspase-3. Results in the present work to comet assay showed less damage to the concentration of $1 \mathrm{mg} \mathrm{L}^{-1}$. Possibly at the highest concentration, repair mechanisms were overexpressed.

\section{Conclusions}

E2 induced cyto-genotoxicity in blood cells of Cyprinus carpio at the concentrations used. This may favor disease development and affect species survival in aquatic ecosystems. The set of assays used in the study constitutes a reliable early warning biomarker for evaluating the toxicity induced on aquatic species by this type of emerging contaminants. The results show that $\mathrm{E} 2$ poses a risk to the animals as common carp to induce cyto and genotoxicty and represents a latent risk to community.

\section{Acknowledgments}

This study was made possible by financial support from the Programa para el Desarrollo Profesional Docente (PRODEP-México, Project 1039503). 


\section{References}

Acconcia, F., Totta, P., Ogawa, S., Cardillo, I., Inoue, S., Leone, S., Trentalance, A., Muramatsu, M., Marino, M., 2005. Survival versus apoptotic 17beta-estradiol effect: role of ER alpha and ER beta activated non-genomic signaling. J. Cell Physiol. 203, 193-201. https://doi.org/10.1002/jcp.20219.

Adeogun, A.O., Ibor, O.R., Adeduntan, S.D., Arukwe, A., 2016. Intersex and alterations in reproductive development of a cichlid, Tilapia guineensis, from a municipal domestic water supply lake (Eleyele) in Southwestern Nigeria. Sci. Total Environ. 541, 372-382. https://doi.org/10.1016/j.scitotenv.2015.09.061.

Baronti, C., Curini, R., D'Ascenzo, G., Di Corcia, A., Gentili, A., Samperi, R., 2000. Monitoring natural and synthetic estrogens at activated sludge sewage treatment plants and in a receiving river water. Environ. Sci. Technol. 34, 5059-5066. https://doi.org/10.1021/es001359q.

Bolognesi, C., Hayashi, M., 2011. Micronucleus assay in aquatic animals. Mutagenesis 26, 205-213. https://doi.org/10.1093/mutage/geq073.

Bolong, N., Ismail, A.F., Salim, M.R., Matsuura, T., 2009. A review of the effects of emerging contaminants in wastewater and options for their removal. Desalination 239 (1-3), 229-246. https://doi.org/10.1016/j.desal.2008.03.020.

Bowman, C.J., Kroll, K.J., Gross, T.G., Denslow, N.D., 2002. Estradiol-induced gene expression in largemouth bass (Micropterus salmoides). Mol. Cell Endocrinol. 196 (1), 67-77. https://doi.org/10.1016/S0303-7207(02)00224-1.

Bradford, M.M., 1976. A rapid and sensitive method for the quantitation of microgram quantities of protein utilizing the principle of protein-dye binding. Anal. Biochem. 72 (1), 248-254. https://doi.org/10.1016/0003-2697(76)90527-3.

Brown, A.R., Hosken, D.J., Balloux, F., Bickley, L.K., LePage, G., Owen, S.F., Hetheridge, M.J., Tyler, C.R., 2009. Genetic variation, inbreeding and chemical exposure-combined effects in wildlife and critical considerations for ecotoxicology. Philos. Trans. R. Soc. B Biol. Sci. 364 (1534), 3377-3390. https://doi.org/ 10.1098/rstb.2009.0126.

Butala, H., Metzger, C., Rimoldi, J., Willett, K.L., 2004. Microsomal estrogen metabolism in channel catfish. Mar. Environ. Res. 58 (2), 489-494. https://doi.org/ 10.1016/j.marenvres.2004.03.034.

Claxton, L.D., Houk, V.S., Hughes, T.J., 1998. Genotoxicity of industrial wastes and effluents. Mutat. Res. 410, 237-243. https://doi.org/10.1016/S1383-5742(98) 00008-8.

Canistro, D., Melega, S., Ranieri, D., Sapone, A., Gustavino, B., Monfrinotti, M., Rizzoni, M., Paolini, M., 2012. Modulation of cytochrome P450 and induction of DNA damage in Cyprinus carpio exposed in situ to surface water treated with chlorine or alternative disinfectants in different seasons. Mutat. Res. 729 (1-2), 81-89. https://doi.org/10.1016/j.mrfmmm.2011.09.008.

Cariño-Cortés, R., Álvarez-González, I., Martino-Roaro, L., Madrigal-Bujaidar, E., 2010. Effect of naringin on the DNA damage induced by daunorubicin in mouse hepatocytes and cardiocytes. Biol. Pharm. Bull. 33, 697-701. https://doi.org/ 10.1248/bpb.33.697.

Cavalieri, E., Rogan, E., 2014. The molecular etiology and prevention of estrogeninitiated cancers: Ockham's Razor: pluralitas non est ponenda sine necessitate. Plurality should not be posited without necessity. Mol. Asp. Med. 36, 1-55. https://doi.org/10.1016/j.mam.2013.08.002.

Cavas, T., Ergene-Gözükara, S., 2005. Induction of micronuclei and nuclear abnormalities in Oreochromis niloticus following exposure to petroleum refinery and chromium processing plant effluents. Aquat. Toxicol. 74, 264-271. https:// doi.org/10.1016/j.aquatox.2005.06.001.

Cavlieri, E., Frenkel, K., Liehr, J.G., Rogan, E., Roy, D., 2000. Estrogens as endogenous genotoxic agents-DNA adducts and mutations. J. Natl. Cancer Inst. Monogr. 27, 75-94.

Commission Directive 92/69/EEC, Annex Part C, C.1- "Acute Toxicity for Fish".

Costa, D.M., Neto, F.F., Costa, M.D.M., Morais, R.N., Garcia, J.R.E., Esquivel, B.M., Ribeiro, C.O., 2010. Vitellogenesis and other physiological responses induced by $17-\beta$-estradiol in males of freshwater fish Rhamdia quelen. Comp. Biochem. Physiol. C. Toxicol. Pharmacol. 151 (2), 248-257. https://doi.org/10.1016/ j.cbpc.2009.11.002.

Dahmer, M.K., 2005. Caspases-2, -3 , and -7 are involved in thapsigargin-induced apoptosis of SH-SY5Y neuroblastoma cells. J. Neurosci. Res. 80, 576-583. https://doi.org/10.1002/jnr.20471.

Darzynkiewicz, Z., Galkowski, D., Zhao, H., 2008. Analysis of apoptosis by cytometry using TUNEL assay. Methods 44 (3), 250-254. https://doi.org/10.1016/ j.ymeth.2007.11.008.

Decordier, I., Dillen, L., Cundari, E., Kirsch-Volders, M., 2002. Elimination of micronucleated cells by apoptosis after treatment with inhibitors of microtubules. Mutagenesis 17, 337-344. https://doi.org/10.1093/mutage/17.4.337.

Díaz-Torres, E., Gibson, R., González-Farías, F., Zarco-Arista, A.E., Mazari-Hiriart, M., 2013. Endocrine disruptors in the Xochimilco wetland, Mexico city. Water Air Soil Poll. 224 (6), 1-11. https://doi.org/10.1007/s11270-013-1586-1.

Duan, W.R., Garner, D.S., Williams, S.D., Funckes-Shippy, C.L., Spath, I.S., Blomme, E.A., 2003. Comparison of immunohistochemistry for activated caspase- 3 and cleaved cytokeratin 18 with the TUNEL method for quantification of apoptosis in histological sections of PC-3 subcutaneous xenografts. J. Pathol. 199 (2), 221-228. https://doi.org/10.1002/path.1289.

Dwivedy, I., Devanesan, P., Cremonesi, P., Rogan, E., Cavilieri, E., 1992. Molecular Origin of cancer: catechol estrogen-3,4-quinones as endogenous tumor initiators. Chem. Res. Toxicol. 5, 828-833. https://doi.org/10.1073/pnas.94.20.10937.

El Habachi, N.M., Maklad, H.M., Sharara, G.M., Allam, E.A., Fawzy, E.M., 2014. A comparative study between the effect of $17-\beta$ estradiol and antioxidants combination on some menopausal changes in oophorectomised rats. Middle East Fertil. Soc. J. 19, 303-313. https://doi.org/10.1016/j.mefs.2014.02.003.

Fadeel, B., Orrenius, S., 2005. Apoptosis: a basic biological phenomenon with wideranging implications in human disease. J. Intern Med. 258, 479-517. https:// doi.org/10.1111/j.1365-2796.2005.01570.x.

Fang, Y.X., Ying, G.G., Zhao, J.L., Chen, F., Liu, S., Zhang, L.J., Yang, B., 2012. Assessment of hormonal activities and genotoxicity of industrial effluents using in vitro bioassays combined with chemical analysis. Environ. Toxicol. Chem. 31, 1273-1282. https://doi.org/10.1002/etc.1811.

Fisher, G.H., Rosenberg, F.J., Straus, S.E., Dale, J.K., Middelton, L.A., Lin, A.Y., Strober, W., Lenardo, M.J., Puck, J.M., 1995. Dominant interfering Fas gene mutations impair apoptosis in a human autoimmune lymphoproliferative syndrome. Cell 81 (6), 935-946. https://doi.org/10.1016/0092-8674(95)900136.

Frenzilli, G., Nigro, M., Lyons, B.P., 2009. The Comet assay for the evaluation of genotoxic impact in aquatic environments. Mutat. Res. 681 (1), 80-92. https:// doi.org/10.1016/j.mrrev.2008.03.001.

Galar-Martínez, M., García-Medina, S., Gómez-Olivan, L.M., Pérez-Coyotl, I., Mendoza-Monroy, D.J., Arrazola-Morgain, R.E., 2015. Oxidative stress and genotoxicity induced by ketorolac on the common carp Cyprinus carpio. Environ. Toxicol. https://doi.org/10.1002/tox.22113.

García-Nieto, E., Juárez-Santacruz, L., García-Gallegos, E., Tlalmis-Zempoalteca, J., Romo-Gómez, C., Torres-Dosal, A., 2014. Genotoxicological response of the common carp (Cyprinus carpio) exposed to spring water in Tlaxcala, Mexico. Bull. Environ. Contam. Toxicol. 93, 393-398. https://doi.org/10.1007/s00128 014-1318-2.

Gutiérrez-Gómez, A.A., San Juan-Reyes, N., Galar-Martínez, M., Dublán-García, O. Islas-Flores, H., García-Medina, S., Pérez-Alvárez, I., Gómez-Oliván, L.M., 2016. $17 \beta$-Estradiol induced oxidative stress in gill, brain, liver, kidney and blood of common carp (Cyprinus carpio). Electron J. Biol. 12, 53-63.

Hayes, C.L., Spink, D.C., Spink, B.C., Cao, J.Q., Walker, N.J., Sutter, T.R., 1996. 17B Estradiol hydroxylation catalyzed by human cytochrome P450 1B1. Proc. Natl. Acad. Sci. U. S. A. 93, 9776-9781.

Heffron, K.T., Gaines, K.F., Novak, J.M., Canam, T., Collard, D.A., 2016. 17ß-Estradiol influent and effluent concentrations in wastewater: demographic influences and the risk to environmental health. Environ. Monit. Assess. 188, 1-14. https:// doi.org/10.1007/s10661-016-5292-5.

Heuser, V.D., de Andrade, V.M., Peres, A., de Macedo Braga, L.M.G., Chies, J.A.B., 2008. Influence of age and sex on the spontaneous DNA damage detected by micronucleus test and comet assay in mice peripheral blood cells. Cell Biol. Int 32 (10), 1223-1229. https://doi.org/10.1016/j.cellbi.2008.07.005.

Hirata, H., Takahashi, A., Kobayashi, S., Yonehara, S., Sawai, H., Okazaki, T., Yamamoto, K., Sasada, M., 1998. Caspases are activated in a branched protease cascade and control distinct downstream processes in Fas-induced apoptosis. J. Exp. Med. 187 (4), 587-600. https://doi.org/10.1084/jem.187.4.587.

Hontela, A., Dumont, P., Duclos, D., Fortin, R., 1995. Endocrine and metabolic dysfunction in yellow perch, Perca flavescens, exposed to organic contaminants and heavy metals in the St. Lawrence River. Environ. Toxicol. Chem. 14 (4) 725-731. https://doi.org/10.1002/etc.5620140421.

Imai, S., Koyama, J., Fujii, K., 2005. Effects of 17b-estradiol on the reproduction of Java-medaka (Oryzias javanicus), a new test fish species. Mar. Pollut. Bull. 51, 708-714. https://doi.org/10.1016/j.marpolbul.2005.02.018.

Kabil, A., Silva, E., Kortenkamp, A., 2008. Estrogens and genomic instability in human breast cancer cells - involvement of Src/Raf/Erk signaling in micronucleus formation by estrogenic chemicals. Carcinogenesis 29, 1862-1868. https:// doi.org/10.1093/carcin/bgn138.

Kang, I.J., Yokota, H., Oshima, Y., Tsuruda, Y., Yamaguchi, T., Maeda, M., Imada, N., Tadokoro, H., Honjo, T., 2002. Effect of $17 \beta$-estradiol on the reproduction of Japanese medaka (Oryzias latipes). Chemosphere 47 (1), 71-80. https://doi.org/ 10.1016/S0045-6535(01)00205-3.

Kim, I.Y., Hyun, C.K., 2006. Comparative evaluation of the alkaline comet assay with the micronucleus test for genotoxicity monitoring using aquatic organisms. Ecotoxicol. Environ. Saf. 64, 288-297. https://doi.org/10.1016/ j.ecoenv.2005.05.019.

Końca, K., Lankoff, A., Banasik, A., Lisowska, H., Kuszewski, T., Góźdź, S., Koza, Z Wojcik, A., 2003. A cross-platform public domain PC image-analysis program for the comet assay. Mutat. Res. Genet. Toxicol. Environ. Mutagen 534 (1), 15-20. https://doi.org/10.1016/S1383-5718(02)00251-6.

Kumar, M.P. D'costa, A., Shyama, S.K., 2017. Genotoxic biomarkers as indicators of marine pollution. In: Mar Pollu Microb Remed. Springer, Singapore, pp. $263-270$

Kumar, P.M.K., Soorambail, S.K., Harisingh, S.B., D'costa, A., Chandra, C.R., 2015. The effect of gamma radiation on the common carp (Cyprinus carpio): In vivo genotoxicity assessment with the micronucleus and comet assays. Mutat. Res. Genet. Toxicol. Environ. Mutagen 792, 19-25. https://doi.org/10.1016 j.mrgentox.2015.08.005.

Kumaravel, T.S., Jha, A.N., 2006. Reliable Comet assay measurements for detecting DNA damage induced by ionising radiation and chemicals. Mutat. Res. Genet. Toxicol. Environ. Mutagen 605 (1), 7-16. https://doi.org/10.1016 j.mrgentox.2006.03.002.

Kumaravel, T.S., Vilhar, B., Faux, S.P., Jha, A.N., 2007. Comet assay measurements: a perspective. Cell Biol. Toxicol. 25 (1), 53-64. https://doi.org/10.1007/s10565007-9043-9.

Kümmerer, K., 2001. Drugs in the environment: emission of drugs, diagnostic aids and disinfectants into wastewater by hospitals in relation to other sources - a 
review. Chemosphere 45, 957-969. https://doi.org/10.1016/S0045-6535(01) 00144-8.

Lawry, J., 2004. Detection of apoptosis by the TUNEL assay. In: Langdon, S.P. (Ed.), Cancer Cell Culture: Methods in Molecular Medicine. Springer, New York, pp. $183-190$.

Lv, L., Dong, X., Gu, Lv, Yu, Y., Zhao, W., Liu, F., 2016. Antioxidant enzymes responses of polychaete Perinereis aibuhitensis following chronic exposure to $17 \mathrm{~b}$-estradiol. Ital. J. Anim. Sci. 15 (3), 552-557. https://doi.org/10.1080/ 1828051X.2016.1194172.

Lee, R.F., Steinert, S., 2003. Use of the single cell gel electrophoresis/Comet Assay for detecting DNA damage in aquatic (marine and freshwater) animals. Mutat. Res. 544 (1), 43-64. https://doi.org/10.1016/S1383-5742(03)00017-6.

Liehr, J.G., Roy, D., 1990. Free radical generation by redox cycling of estrogens. Free Radic. Biol. Med. 8 (4), 415-423. https://doi.org/10.1016/0891-5849(90)90108U.

Ma, L., Yates, S.R., Ashworth, D., 2016. Parent and conjugated estrogens and progestagens in surface water of the Santa Ana River: determination, occurrence and risk assessment. Environ. Toxicol. Chem. https://doi.org/10.1002/etc.3447.

Maria, V.L., Ahmad, I., Santos, M.A., 2008. Juvenile sea bass (Dicentrarchus labrax L.) DNA strand breaks and lipid peroxidation response following $17 \beta$-estradiol two mode of exposures. Environ. Int. 34, 23-29. https://doi.org/10.1016/ j.envint.2007.06.008.

Marlatt, V., Hewitt, M., Van Der Kraak, G., 2006. Utility of in vitro test methods to assess the activity of xenoestrogens in fish. Environ. Toxicol. Chem. 12 3204-3212. https://doi.org/10.1897/05-686R.1.

Martínez-Tabche, L., Madrigal-Bujaidar, E., Negrete, T., 2004. Genotoxicity and lipoperoxidation produced by paraquat and 2, 4-dichlorophenoxyacetic acid in the gills of rainbow trout (Oncorhynchus mykiss). Bull. Environ. Contam. Toxicol. 73, 146-152. https://doi.org/10.1007/s00128-004-0406-0.

Matozzo, V., Marin, M.G., 2008. Can 17- $\beta$ estradiol induce vitellogenin-like proteins in the clam Tapes philippinarum? Environ. Toxicol. Pharmacol. 26, 38-44. https://doi.org/10.1016/j.etap.2008.01.001.

Mauras, N., Santen, R.J., Colón-Otero, G., Hossain, J., Wang, Q., Mesaros, C., Blair, I.A., 2015. Estrogens and their genotoxic metabolites are increased in obese prepubertal girls. J. Clin. Endocrinol. Metab. 100, 2322-2328. https://doi.org/ 10.1210/jc.2015-1495.

Mills, L.J., Gutjahr-Gobell, R.E., Haebler, R.A., Horowitz, D.J.B., Jayaraman, S., Pruell, R.J., McKinney, R.A., Gardner, G.R., Zaroogian, G.E., 2001. Effects of estrogenic (o,p'-DDT; octylphenol) and anti-androgenic (p,p'-DDE) chemicals on indicators of endocrine status in juvenile male summer flounder (Paralichthys dentatus). Aquat. Toxicol. 52 (2), 157-176. https://doi.org/10.1016/S0166445X(00)00139-9.

Mitchelmore, C.L., Chipman, J.K., 1998. DNA strand breakage in aquatic organisms and the potential value of the comet assay in environmental monitoring. Aquat. Toxicol. 41, 161-182. https://doi.org/10.1016/S0027-5107(97)00252-2.

Mishra, D.P., Shaha, C., 2005. Estrogen-induced spermatogenic cell apoptosis occurs via the mitochondrial pathway: role of superoxide and nitric oxide. J. Biol. Chem. 280, 6181-6196. https://doi.org/10.1074/jbc.M405970200.

Munkttrick, K.R.M., Van Der Kraak, G.J., McMaster, M.E., Portt, C.B., 1992. Response of hepatic MFO activity and plasma sex steroids to secondary treatment of bleached kraft pulp mill effluent and mill shutdown. Environ. Toxicol. Chem. 11 (10), 1427-1439. https://doi.org/10.1002/etc.5620111008.

Nacci, D.E., Cayula, S., Jackim, E., 1996. Detection of DNA damage in individual cells from marine organisms using the single cell gel assay. Aquat. Toxicol. 35, 197-210. https://doi.org/10.1016/0166-445X(96)00016-1.

Nadzialek, S., Kestemont, P., 2010. 17 $\alpha$-Ethinylestradiol induces an imbalance between apoptosis and cell proliferation to sex steroid disruption in a testis culture of gudgeon, Gobio gobio. Environ. Toxicol. Chem. 29, 881-886. https:// doi.org/10.1002/etc.100.

Nesslany, F., Benameur, L., 2014. Genotoxicity of nanoparticles. Encycl. Nanotechnol. 1-11. https://doi.org/10.1007/978-94-007-6178-0_335-2.

Norbury, C.J., Zhivotovsky, B., 2004. DNA damage-induced apoptosis. Oncogene 23 (16), 2797.

Nutter, L.M., Wu, Y.Y., Ngo, E.O., Sierra, E.E., Gutierrez, P.L., Abul-Hajj, Y.J., 1994. An oquinone form of estrogen produces free radicals in human breast cancer cells: correlation with DNA damage. Chem. Res. Toxicol. 7, 23-28. https://doi.org/ $10.1021 / \mathrm{tx} 00037 \mathrm{a} 004$.

Petrie, B., Barden, R., Kasprzyk-Hordern, B., 2015. A review on emerging contaminants in wastewaters and the environment: current knowledge, understudied areas and recommendations for future monitoring. Water Res. 72, 3-27. https:// doi.org/10.1016/j.watres.2014.08.053.

Reinardy, H.C., Syrett, J.R., Jeffree, R.A., 2013. Cobalt-induced genotoxicity in male zebrafish (Danio rerio), with implications for reproduction and expression of DNA repair genes. Aquat. Toxicol. 126, 224-230. https://doi.org/10.1016/ j.aquatox.2012.11.007.

Richardson, S.D., Kimura, S.Y., 2016. Water analysis: emerging contaminants and current issues. Anal. Chem. 88, 546-582. https://doi.org/10.1021/ac900801.

Roos, W.P., Kaina, B., 2006. DNA damage-induced cell death by apoptosis. Trends Mol. Med. 12, 440-450. https://doi.org/10.1016/j.molmed.2006.07.007.
Routledge, E.J., Sheahan, D., Desbrow, C., Brighty, G.C., Waldock, M., Sumpter, J.P., 1998. Identification of estrogenic chemicals in STW effluent. 2. In vivo responses in trout and roach. Environ. Sci. Technol. 32, 1559-1565. https://doi.org/ 10.1021/es970796a.

Sackett, D.K., Pow, C.L., Rubino, M.J., Aday, D.D., Cope, W.G., Kullman, S., Rice, J.A., Kwak, T.J., Law, M., 2015. Sources of endocrine-disrupting compounds in North Carolina waterways: a geographic information systems approach. Environ. Toxicol. Chem. 34 (2), 437-445. https://doi.org/10.1002/etc.2797.

Sharma, R., Masaki, J., Agarwal, A., 2013. Sperm DNA fragmentation analysis using the TUNEL assay. In: Spermatogenesis: Methods and Protocols. Springer, New York, pp. 121-136.

Selvi, M., Çavaş, T., Cağlan Karasu Benli, A., Koçak Memmi, B., Çinkılıç, N., Dinçel, A.S., Vatan, O., Yılmaz, D., Sarıkaya, R., Zorlu, T., Erkoç, F., 2013. Sublethal toxicity of esbiothrin relationship with total antioxidant status and in vivo genotoxicity assessment in fish (Cyprinus carpio L., 1758) using the micronucleus test and comet assay. Environ. Toxicol. 28, 644-651. https://doi.org/ 10.1002/tox.20760.

Simoes, V.L., Alves, M.G., Martins, A.D., Dias, T.R., Rato, L., Socorro, S., Oliveira, P.F., 2013. Regulation of apoptotic signaling pathways by $5 \alpha$-dihydrotestosterone and $17 \beta$-estradiol in immature rat Sertoli cells. J. Steroid Biochem. Mol. Biol. 135, 15-23. https://doi.org/10.1016/j.jsbmb.2012.11.019.

Sweet, L.I., Passino-Reader, D.R., Meier, P.G., Omann, G.M., 1999. Xenobiotic-induced apoptosis: significance and potential application as a general biomarker of response. Biomarkers 4 (4), 237-253. https://doi.org/10.1080/ 135475099230778.

Teles, M., Pacheco, M., Santos, M.A., 2005. Sparus aurata L. liver EROD and GST activities, plasma cortisol, lactate, glucose and erythrocytic nuclear anomalies following short-term exposure either to $17 \beta$-estradiol (E2) or E2 combined with 4-nonylphenol. Sci. Total Environ. 336, 57-69. https://doi.org/10.1016/ j.scitotenv.2004.05.004.

Teles, M., Pacheco, M., Santos, M.A., 2006. Biotransformation, stress and genotoxic effects of $17 \beta$-estradiol in juvenile sea bass (Dicentrarchus labrax L.). Environ. Int. 32 (4), 470-477. https://doi.org/10.1016/j.envint.2005.11.006.

Tetreault, G.R., Bennett, C.J., Shires, K., Knight, B., Servos, M.R., McMaster, M.E., 2011. Intersex and reproductive impairment of wild fish exposed to multiple municipal wastewater discharges. Aquat. Toxicol. 104, 278-290. https://doi.org/ 10.1016/j.aquatox.2011.05.008.

Thilagam, H., Gopalakrishnan, S., Bo, J., Wang, K.J., 2014. Comparative study of $17 \beta-$ estradiol on endocrine disruption and biotransformation in fingerlings and juveniles of Japanese sea bass Lateolabrax japonicus. Mar. Pollut. Bull. 85, 332-337. https://doi.org/10.1016/j.marpolbul.2014.05.024.

Thilagam, H., Gopalakrishnan, S., Qu, H.D., Bo, J., Wang, K.J., 2010. $17 \beta$ estradiol induced ROS generation, DNA damage and enzymatic responses in the hepatic tissue of Japanese sea bass. Ecotoxicology 19, 1258-1267. https://doi.org/ 10.1007/s10646-010-0510-3.

Udroiu, I., 2006. The micronucleus test in piscine erythrocytes. Aquat. Toxicol. 79, 201-204. https://doi.org/10.1016/j.aquatox.2006.06.013.

Van der Oost, R., Beyer, J., Vermeulen, N.P., 2003. Fish bioaccumulation and biomarkers in environmental risk assessment: a review. Environ. Toxicol. Pharmacol. 13 (2), 57-149. https://doi.org/10.1016/S1382-6689(02)00126-6.

Vasquez, M.Z., 2012. Recommendations for safety testing with the in vivo comet assay. Mutat. Res. Genet. Toxicol. Environ. Mutagen 747, 142-156. https:// doi.org/10.1016/j.mrgentox.2012.05.002.

Vazzana, M., Celi, M., Tramati, C., Ferrantelli, V., Arizza, V., Parrinello, N., 2014. In vitro effect of cadmium and copper on separated blood leukocytes of Dicentrarchus labrax. Ecotoxicol. Environ. Saf. 102, 113-120. https://doi.org/ 10.1016/j.ecoenv.2014.01.018.

Wang, Z., Zheng, Q., Liu, K., Li, G., Zheng, R., 2006. Ginsenoside Rh2 enhances antitumour activity and decreases genotoxic effect of cyclophosphamide. Basic Clin. Pharmacol. Toxicol. 98 (4), 411-415. https://doi.org/10.1111/j.17427843.2006.pto_348.x.

Williams, T.D., Diab, A.M., George, S.G., Sabine, V., Chipman, J.K., 2007. Gene expression responses of European flounder (Platichthys flesus) to 17-ßestradiol. Toxicol. Lett. 168, 236-248. https://doi.org/10.1016/j.toxlet.2006.10.020.

Yan, Z., Lu, G., Wu, D., Ye, Q., Xie, Z., 2013a. Interaction of 17ß-estradiol and ketoconazole on endocrine function in goldfish (Carassius auratus). Aquat. Toxicol. 132, 19-25. https://doi.org/10.1016/j.aquatox.2013.01.015.

Yan, Z.H., Lu, G.H., Yang, X.F., 2013b. Single and combined effects of estrone and $17 \beta-$ estradiol on male goldfish. Biomed. Environ. Sci. 26, 176-184. https://doi.org/ 10.3967/0895-3988.2013.03.004.

Zhang, Y., Zhou, J.L., Ning, B., 2007. Photodegradation of estrone and $17 \beta$-estradiol in water. Water Res. 41 (1), 19-26. https://doi.org/10.1016/j.watres.2006.09.020.

Zhou, B.B.S., Elledge, S.J., 2000. The DNA damage response: putting checkpoints in perspective. Nature 408 (6811), 433-439.

Zhu, C., Wang, X., Hagberg, H., Blomgren, K., 2000. Correlation between Caspase-3 activation and three different markers of DNA damage in neonatal cerebral hypoxia-ischemia. J. Neurochem. 75 (2), 819-829. https://doi.org/10.1046/ j.1471-4159.2000.0750819.x. 